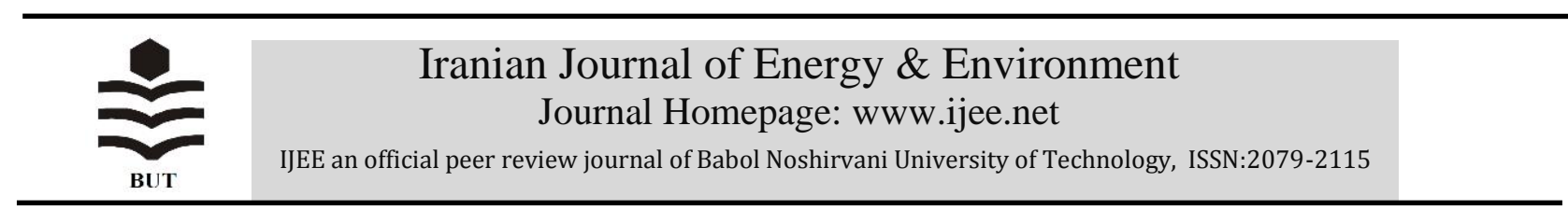

\title{
Performance Analysis of a Microbial Fuel Cell Using Different Substrate Materials for Different loads
}

\author{
U. S. Shehab ${ }^{1 *}$, R. K. Shoffiuddin ${ }^{2}$, U. S. Nayeem ${ }^{3}$, S. AHM ${ }^{2}$
}

${ }^{1}$ Institute of Energy, University of Dhaka, Dhaka, Bangladesh.

${ }^{2}$ Electrical and Electronic Engineering Department, American International University Bangladesh, Dhaka-1213, Bangladesh ${ }^{3}$ Electrical and Electronic Engineering Department, Ahsanullah University of Science \& Technology, Dhaka-1208, Bangladesh

\section{PAPER INFO}

Paper history:

Received 12 September 2018

Accepted in revised form 21 Occtober 2018

\section{Keywords:}

Microbial fuel cell (MFC)

Saltbridge

Potassium ferricyanide

\begin{abstract}
A B S S T R A C T
This research paper analyses the current density and power density ofaduelchambermicrobial fuel cell using different substrate materials for different resistive loads. Sucrose, glucose and starch were treated as substrate and potassium ferricyanide was used as electron acceptor. The separation of the cathode and anode cell is provided by proton exchange membrane (PEM) in most of the microbial fuel cell (MFC). The most popular proton exchange membranes are nafion, hyflon, zirfon, ultrex CMI-7000 etc. But all of them are not available to use in this part of the world. As an alternate, salt bridge was used in this study as a PEM which is receptive to other ions and chemicals. Different organic materials like sucrose, glucose, starch can be used as substrate as those were available in organic wastage. As the container of bacteria, the sludge of drain of DhakaTreatment Plant was utilized. The voltage and current were measured across $9.81 \mathrm{k} \Omega$ and $5.91 \mathrm{k} \Omega$ resistors. $716.32 \mathrm{mV}$ was measured as thehighest voltage across $9.81 \mathrm{k} \Omega$ resistor while $4.65 \mathrm{~mA} / \mathrm{m} 2$ and $3.09 \mathrm{~mW} / \mathrm{m} 2$ were recorded as maximum current density and power density respectively across $5.91 \mathrm{k} \Omega$ resistor for sucrose as substrate. The anode chamber was maintained in anaerobic condition. The temperature during these experiments was $22 \pm 2^{\circ} \mathrm{C}$.
\end{abstract}

doi: $10.5829 /$ ijee.2018.09.03.06

\section{INTRODUCTION}

As the energy sources are not sustainable due to the majority share of fossil fuel in energy mix, Bangladesh is an energy deficit country $[1,2]$. On the contrary per capita waste generation rate is computed as 0.56 $\mathrm{kg} /$ capita/day based on the total estimated urban population of the year 2005. In Dhaka city of Bangladesh $4,634.52$ tons wastes aredaily generated and $76 \%$ is from residential sector [3-5]. Generation of electricity and treatment of organic or inorganic wastes can be achieved by the microbial fuel cell.A new form of renewable energy by generating electricity from what would otherwise be considered waste was represented by Microbial fuel cell (MFC) technology. MFCs are electrochemical devices that are similar to conventional fuel cells in which energy from a chemical reaction is converted into useful electricity. This technology can use bacteria already present in wastewater as biocatalysts to generate electricity while simultaneously wastewater istreated [6,7]. Anode and cathode chambers are the compulsory parts of an MFC connected by an external circuit and detached by proton exchange membrane (PEM). Decomposition of organic substrates by microbes produces electrons and protons in the anode chamber. Those electrons and protons are transported through external circuit and proton exchange membrane respectively to the cathode [8]. Electrochemically active microorganisms (EAM) are employed to generate electricity the MFC device which is capable of providing the energy demands for small devices $[9,10]$. While accomplishing biodegradation of organic matters and wastes in the MFC, as microbe is the most preferred to generate electricity $[11,12]$. Hydrogen can be produced in Microbial Fuel Cell and it happens smoothly from the fermentation of sucrose in presence of Clostridium butyricum, as overall biochemical reaction is given as follows[13]:

$$
\mathrm{C}_{12} \mathrm{H}_{22} \mathrm{O}_{11}+13 \mathrm{H}_{2} \mathrm{O} \rightarrow 12 \mathrm{CO}_{2}+48 \mathrm{H}^{+}+48 \mathrm{e}^{-}
$$

\section{MATERIAL AND METHOD \\ Microbial fuel cell operation}

In MFCs, a substrate as carbon source is consumed by microorganisms in anaerobic conditions, produce carbon dioxide, electrons and protons in anode chamber [14]. The simplified FMC concept is shown in Figure 1. 


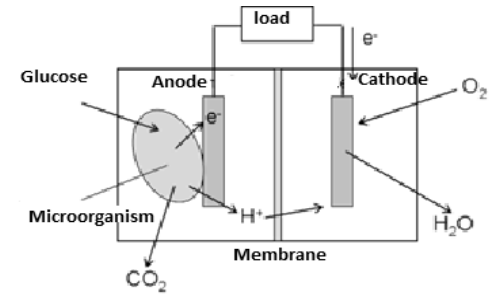

Figure 1. Schematic diagram of simplified MFC unit

Electrons are transferred to the negative terminal (anode) and reach to the positive terminal (cathode) through a load which are produced from the substrates by microorganisms. Several chemicals known as mediators like neutral red, methylene blue, thionine are used to accelerate the generation of current in MFC. Protons are also produced in oxidation reaction and passed to the cathode by proton exchange membrane. Direct link between the electrode surface and membrane bound proteins or by conduction through nanowires by microorganism that contact cells to the electrode surface is responsible for the transfer of electrons [15].

\section{Standard electrode potentials}

The half-cell reactions can analyzereactions occurring in the microbial fuel cellstated as follows:

$$
2 \mathrm{CH}_{3} \mathrm{COO}^{-}=\mathrm{CH}_{3} \mathrm{CH}_{3}+\mathrm{CO}_{2}+2 \mathrm{e}^{-}
$$

For sucrose oxidation, we therefore have,

$\mathrm{E}_{\mathrm{AN}}=\mathrm{E}^{0}{ }_{\mathrm{AN}}-(\mathrm{RT} / 2 \mathrm{~F}) \ln \left[\left(\mathrm{CH}_{3} \mathrm{COO}^{-}\right)^{2} /\left(\mathrm{CH}_{3}\right.\right.$

$\left.\left.\mathrm{CH}_{3}\right)\right]$

For the cathode potential Ecat if we consider the case where Potassium Ferricyanide is used as the electron acceptor for the reaction, we can written as follows:

$$
\begin{aligned}
& \mathrm{Fe}(\mathrm{CN})_{6}^{3-}+\mathrm{e}^{-}=\mathrm{Fe}(\mathrm{CN})_{6}^{4-} \\
& \mathrm{E}_{\mathrm{cat}}=\mathrm{E}^{0}{ }_{\text {cat }}-(\mathrm{RT} / \mathrm{F}) \ln \left[\left(\mathrm{Fe}(\mathrm{CN})_{6}{ }^{4-}\right) /(\mathrm{Fe}\right. \\
& \left.\left.(\mathrm{CN})_{6}^{3-}\right)\right] \\
& \text { The Cell EMF is computed as follows }[8]: \\
& \mathrm{E}_{\mathrm{emf}}=\mathrm{E}_{\mathrm{cat}}-\mathrm{E}_{\mathrm{An}}
\end{aligned}
$$

\section{Proposed model for microbial fuel cell}

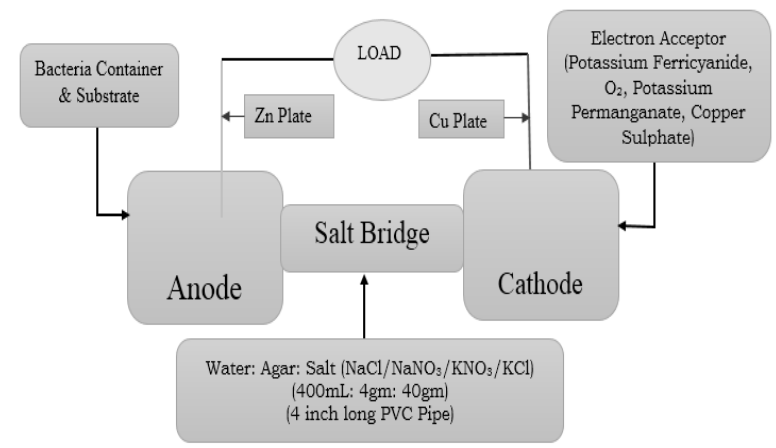

Figure 2. An alternative model of MFC
The configuration shown in Figure 2 is an ideal model for the replacement of simple MFC diagram shown in previous figure. The proposed model is a dual compartment MFC. But it may be multi-compartments depending on the desired output. There must a separation required between each anode and cathode compartment. The separator may be salt bridge or proton exchange membrane. The market of nafion membrane is limited and cost is quite high. The salt bridge is made of water, Agar $\left(\mathrm{Cl}_{4} \mathrm{H}_{24} \mathrm{O}_{9}\right)$ and salt. Sodium Chloride $(\mathrm{NaCl})$, Sodium Nitrate $\left(\mathrm{NaNO}_{3}\right)$, Potassium Chloride $(\mathrm{KCl})$, Potassium Nitrate $\left(\mathrm{KNO}_{3}\right)$ etc. can be used as the sample of salt. For construction of a salt bridge the ratio of water, agar and salt is $50 \mathrm{~mL}, 1 \mathrm{~g}, 5 \mathrm{~g}$. respectively for per inch. The measurement is suitable for 0.5 -inch-thick salt bridge. In anode chamber bacteria container can be used. It may be drain water, slurry of biogas plant, cow dung, human waste, rice washing water. Any type of material containing bacteria can be used in the anode chamber. As substrate materials, different organic materials can be used. Sucrose, glucose, starch etc are included as substrate material. Any type of mediators like methylene blue, thionine, neutral red etc is excluded in this model as they are costly but less effective. So the proposed model is "mediatorless" MFC. Zinc plate is used as anode electrode whereas copper plate is used as cathode electrode. Graphite rod can be also used as electrodes. Electron acceptors are kept in the cathode compartment. Oxygen $\left(\mathrm{O}_{2}\right)$, Copper Sulphate $\left(\mathrm{CuSO}_{4}\right)$, Potassium Permanganate $\left(\mathrm{KMnO}_{4}\right)$, Potassium Ferricyanide $\left(\mathrm{K}_{3}\left[\mathrm{Fe}(\mathrm{CN})_{6}\right]\right)$ etc can be used in the cathode compartment.

\section{Experimental setup and data analysis}

Based on the proposed model three setups were developed and observed. All the cells were kept in anaerobic condition and readings were measured across no load, $5.91 \mathrm{k} \Omega$ and $9.84 \mathrm{k} \Omega$. Equal amount of surface area was provided for each of the experiments. Plastic bottles were use to construct anode and cathode chamber. The anode surface area was $0.0242 \mathrm{~m}^{2}$. The temperature during these experiments was $22 \pm 2^{\circ} \mathrm{C}$. The measurements were taken using a multimeter (Model no. KOOCU-DT9205A).

\section{RESULTS AND DISCUSSION Preparation of Salt bridge}

The materials mentioned in the proposed model were used to construct the salt bridges. Sodium chloride was used as the sample of salt to mix with agar powder. Each salt bridge was 5 -inch-long and 0.5 inch thick. It consists of $5 \mathrm{~g}$ agar, $25 \mathrm{~g}$ sodium chloride as the salt sample dissolved in $250 \mathrm{~mL}$ of water for construction of the salt bridge. At first all the components were taken in a pot 
then the materials were mixed during the heating process. The mixture was heated until the temperature reached $85^{\circ} \mathrm{C}$. The hot solution was poured into PVC pipes having length of 5 inch and thickness of 0.5 inch. The temperature was measured by a digital thermometer. The dimensions of different parts of constructed MFC for setup 1, 2 and 3 are provided in Table 1 .

\section{Setup 1}

For the first setup $400 \mathrm{~mL}$ of Potassium Ferricyanide was used in cathode chamber. Zinc and copper plates were used as electrode material in anode and cathode compartments, respectively. A salt bridge was placed between anode and cathode to provide a chanel for the protons to pass from anode to cathode. The amount of starch used was $125 \mathrm{~g}$. As the container of bacteria thick muddy layer of Dhaka North City Corporation's drain was used. At first $1 \mathrm{~kg}$ of muddy layer was mixed with 0.25 litre of drain water. Then 0.5 litre liquid was used from that mixture in the anode chamber. The measured voltage, current and power obtained from setup 1 were represented in Figures 3, 4 and 5, respectively. From setup 1, the highest open circuit voltage was recorded $650.2 \mathrm{mV}$. In addition, $587.65 \mathrm{mV}$ was measured as highest voltage and $35.2 \mu \mathrm{W}$ was recorded as maximum power across $9.81 \mathrm{k} \Omega$ resistor while $73.73 \mu \mathrm{A}$ was measured as maximum current across $5.91 \mathrm{k} \Omega$ resistor for setup 1 .

TABLE 1. Dimensions of different parts of constructed mfc

\begin{tabular}{cccccc}
\hline Set & $\begin{array}{c}\text { Anode and } \\
\text { cathode } \\
\text { chambers }\end{array}$ & \multicolumn{2}{c}{$\begin{array}{c}\text { Electrode (anode } \\
\text { and cathode) }\end{array}$} & \multicolumn{2}{c}{ Salt bridge } \\
\cline { 3 - 6 } No. & area $\left(\mathbf{m}^{2}\right)$ & $\begin{array}{c}\text { Length } \\
(\mathbf{m})\end{array}$ & $\begin{array}{c}\text { Width } \\
(\mathbf{m})\end{array}$ & $\begin{array}{c}\text { Surface } \\
\text { area } \\
\left(\mathbf{m}^{2}\right)\end{array}$ & $\begin{array}{c}\text { Length } \\
(\mathbf{m})\end{array}$ \\
\hline 1 & 0.069 & 0.076 & 0.127 & 0.00025 & 0.127 \\
2 & 0.069 & 0.076 & 0.127 & 0.00025 & 0.127 \\
3 & 0.069 & 0.076 & 0.127 & 0.00025 & 0.127 \\
\hline
\end{tabular}

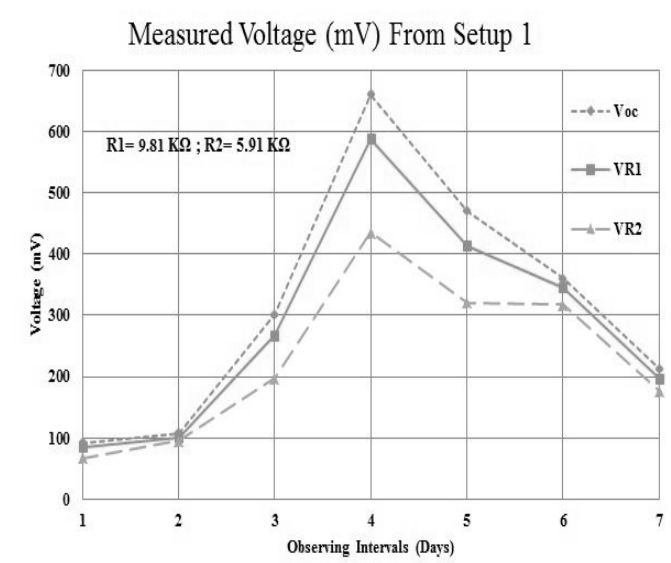

Figure 3. Measured voltage (mV) from setup 1 for different loads

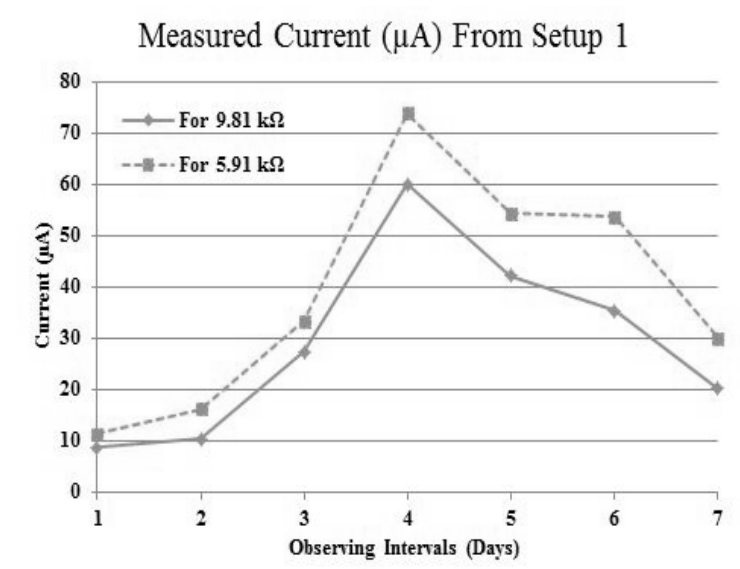

Figure 4. Measured current $(\mu \mathrm{A})$ from setup 1 for different loads

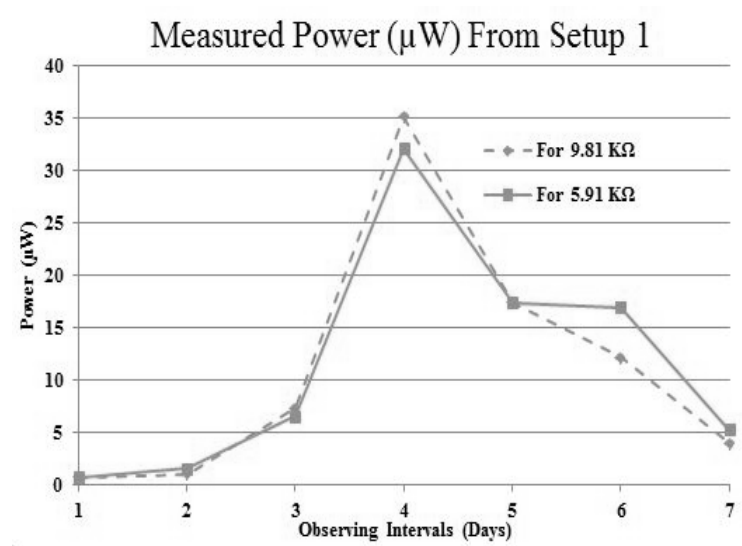

Figure 5. Measured power $(\mu \mathrm{W})$ from Setup 1 for different loads

\section{Setup 2}

For the second setup all the materials remained the same like setup 1 except $125 \mathrm{~g}$ of sucrose was used instead of starch. From setup 2, the highest open circuit voltage was obtained $773.5 \mathrm{mV}$. While, $716.32 \mathrm{mV}$ was measured as highest voltage across $9.81 \mathrm{k} \Omega$ resistor also $112.42 \mu \mathrm{A}$ and $74.7 \mu \mathrm{W}$ were recorded as maximum current and power respectively across $5.91 \mathrm{k} \Omega$ resistor for setup 2 . The measured voltage, current and power obtained from setup 2 were represented by Figures 6, 7 and 8, respectively.

\section{Setup 3}

For the third setup again all the materials remained the same like setup 2 except $125 \mathrm{~g}$ of glucose was used instead of starch. From setup 3, the highest open circuit voltage was obtained $610.2 \mathrm{mV}$. also, $567.63 \mathrm{mV}$ was measured as the highest voltage across $9.81 \mathrm{k} \Omega$ resistor while $81.94 \mu \mathrm{A}$ and $56.52 \mu \mathrm{W}$ were recorded as maximum current and power respectively across $5.91 \mathrm{k} \Omega$ resistor for setup 3. The measured voltage, current and power obtained from setup 3 are represented in Figures 9,10 and 11 , respectively. 


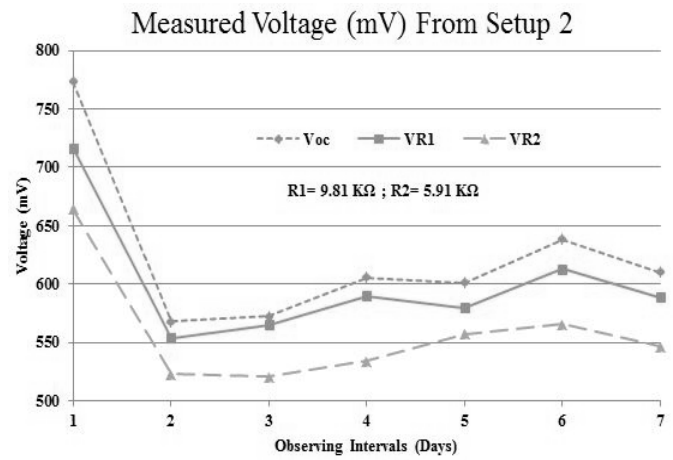

Figure 6. Measured voltage $(\mathrm{mV})$ from setup 2 for different loads

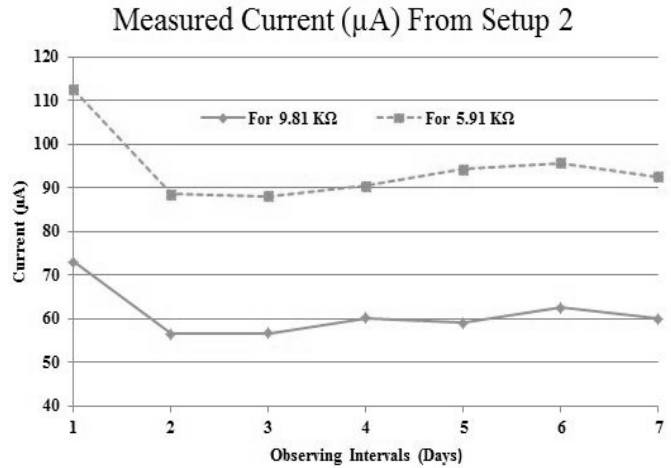

Figure7. Measured current $(\mu \mathrm{A})$ from setup 2 for different loads

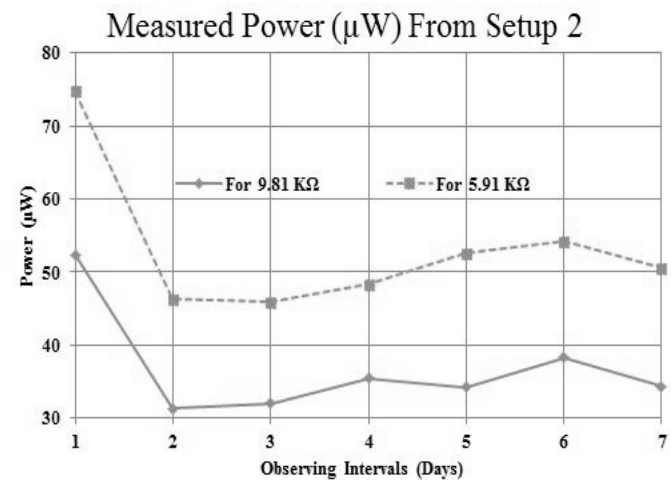

Figure 8. Measured power $(\mu \mathrm{W})$ from setup 2 for different loads

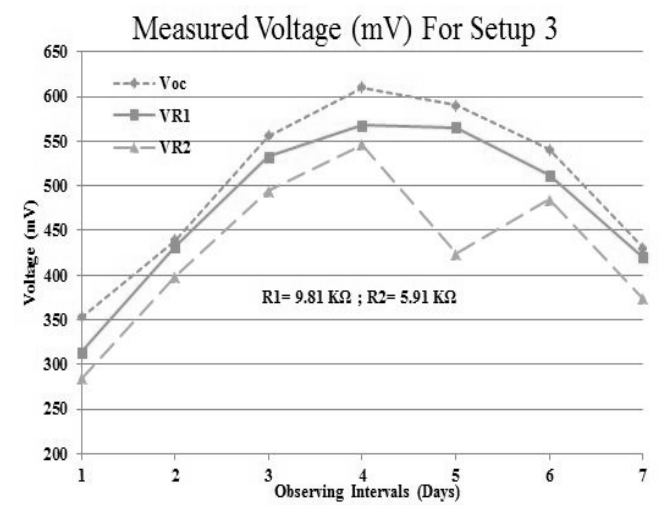

Figure 9. Measured voltage $(\mathrm{mV})$ from setup 3 for different loads

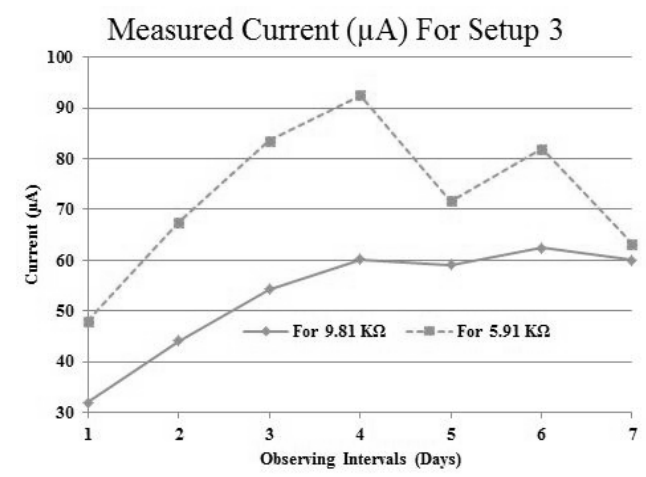

Figure 10. Measured current $(\mu \mathrm{A})$ from setup 3 for different loads

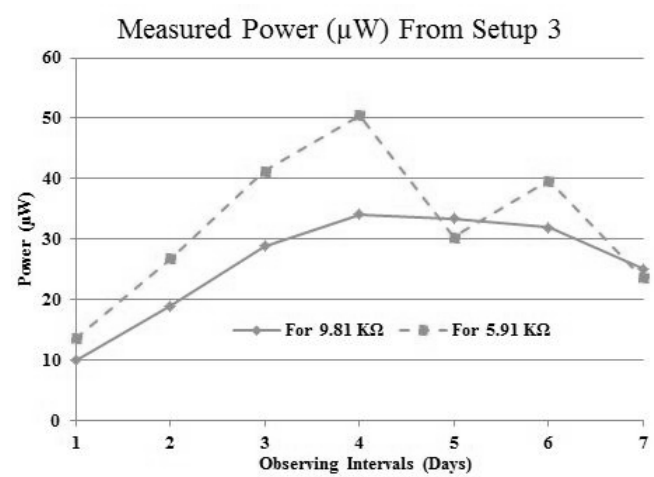

Figure 11. Measured power $(\mu \mathrm{W})$ from setup 3 for different loads

\section{Comparisons among practical setups}

Two resistors $(9.81 \mathrm{k} \Omega$ and $5.91 \mathrm{k} \Omega$ ) were treated as the load to measure the current generated by the MFC. The values of the current were obtained in micro range (10-6) which leads to inadequate power production from the experiments. The maximum current density recorded for setup 1, setup 2 and set up 3 were $3.05 \mathrm{~mA} / \mathrm{m} 2,4.65$ $\mathrm{mA} / \mathrm{m} 2,3.46 \mathrm{~mA} / \mathrm{m} 2$, respectively. The maximum power density recorded for setup 1 , setup 2 and set up 3 were $3.05 \mathrm{~mW} / \mathrm{m} 2,3.09 \mathrm{~mW} / \mathrm{m} 2,2,09 \mathrm{~mW} / \mathrm{m} 2$, respectively. All the cells were kept in below 250C. From the result recorded it is seen that sucrose provided more stable outputs than other substrates. As all the substrates used here are available in organic wastes (like rotten rice, vegetables) so these experiments will show the way to utilize the wastes in a desired manor through MFCs. The current density and power density obtained against 9.81 $\mathrm{k} \Omega$ and $5.91 \mathrm{k} \Omega$ from three setups are illustrated in Figures 12,13, 14 and 15, respectively.

\section{CONCLUSIONS}

Alternative energy production technologies are gaining importance for battling future energy crisis. MFCs could be an effective means to accelerate bioelectricity production. This paper was unable to examine the entire field of MFC research in detail but hopes to highlight 
some important points. Low current density is a barrier for implementation of MFC in practical level. A parallel combination of such type of MFC could increase the current value in a modest level might be a formal solution. Further researches about bacteria and anode, cathode material could lead this experiment in a fruitful situation.

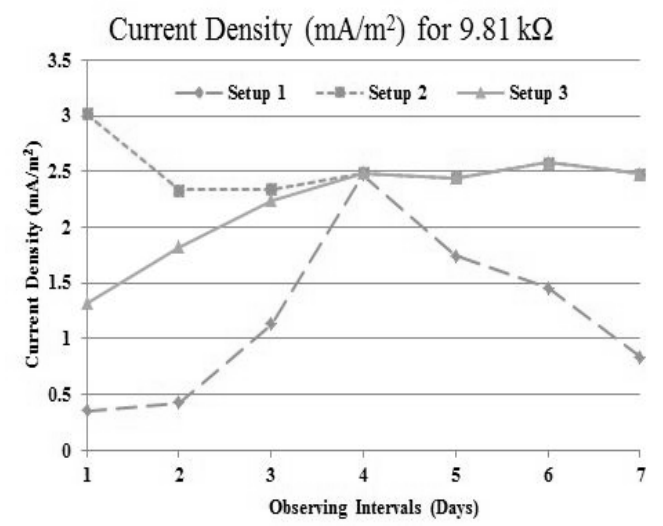

Figure12. Current Density (mA/m2) for $9.81 \mathrm{k} \Omega$

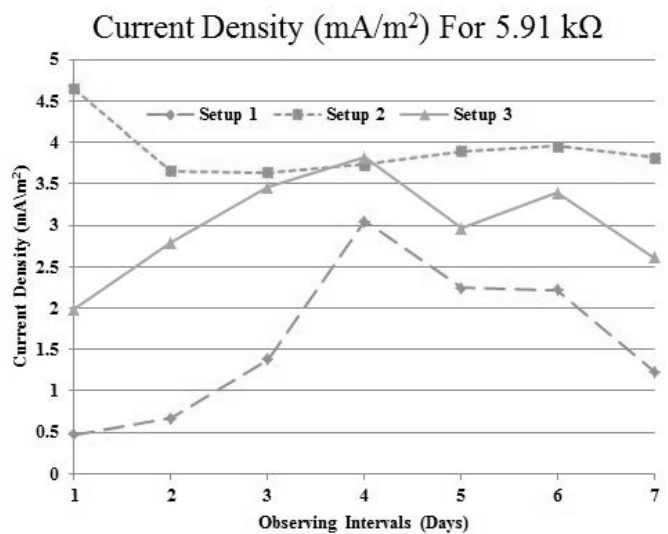

Figure13. Current density $(\mathrm{mA} / \mathrm{m} 2)$ for $5.91 \mathrm{k} \Omega$

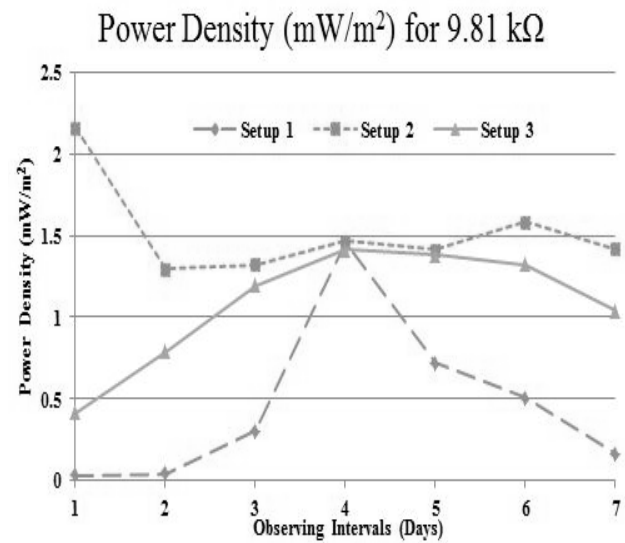

Figure 14. Power density $(\mathrm{mW} / \mathrm{m} 2)$ for $9.81 \mathrm{k} \Omega$

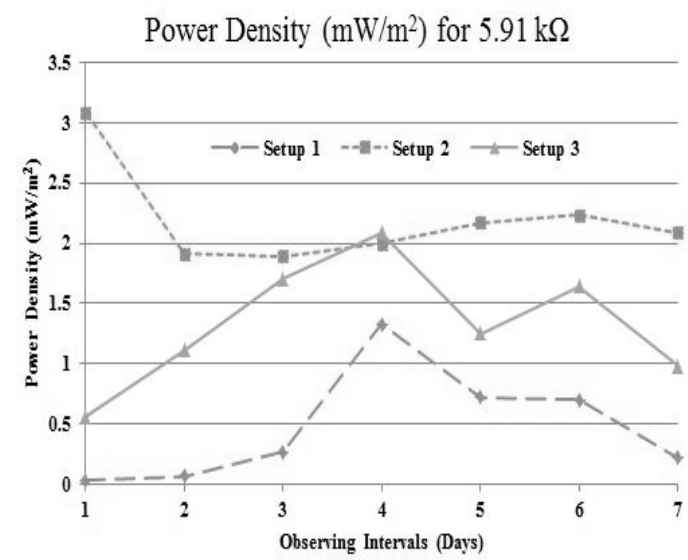

Figure 15. Power Density $(\mathrm{mW} / \mathrm{m} 2)$ for $5.91 \mathrm{k} \Omega$

\section{REFERENCES}

1. A. K Hossain and O. Badr, 2007 "Prospects of renewable energy utilisation for electricity generation in Bangladesh," Renewable and Sustainable Energy Reviews, vol. 11, no. 8, pp. 1617-1649.

2. S. Shahid, 2012 "Vulnerability of the power sector of Bangladesh to climate change and extreme weather events," Regional Environmental Change, vol. 12, no. 3, pp. 595-606.

3. Alamgir M. and Ahsan. A. 2007, Municipal Solid Waste and Recovery Potential: Bangladesh Perspective. Iran. Journal of Environmental Health, Science and Engineering; 4 (2): 67-76.

4. Enayetullah I, Sinha AHMM, Khan SSA. 2005, Urban Solid Waste Management Scenario of Bangladesh: Problems and Prospects. Waste Concern Technical Documentation, Dhaka, Bangladesh; 18.

5. Bahauddin KM and Uddin MH. 2012, Prospect of Solid Waste Situation and an Approach of Environmental Management Measure (EMM) Model for Sustainable Solid Waste Management: Case Study of Dhaka City. Journal of Environmental Science and Natural Resources; 5 (1): 99-111.

6. Liu H, Ramnarayanan R, Logan BE. 2004, Production of electricity during wastewater treatment using a single chamber microbial fuel cell. Environmental science \& Technology; 38(7): 2281-2285.

7. Min B, Logan BE. 2004, Continuous electricity generation from domestic wastewater and organic substrates in a flat plate microbial fuel cell. Environmental Science \& Technology; 38: 5809-5814.

8. B.E. Logan, B. Hamelers, R. Rozendal, U. Schro “ der, J. Keller, S. Freguia, P. Aelterman, W.Verstraete, K. Rabaey, 2006,"Microbial fuel cells: methodology and technology," Environmental Science \& Technology; 40, pp. 5181-5192. 
9. Logan BE. Exoelectrogenic bacteria that power microbial fuel cells. Nature reviews. Microbiology, 2009; 7: 375 381.

10. Moqsud M.A, Omine K, Yasufuku N, Hyodo M, Nakata Y. 2013, Microbial fuel cell (MFC) for bioelectricity generation from organic wastes. Waste Management,; 33: 2465-2469.

11. Park DH, Zeikus JG. 2000, Electricity generation in microbial fuel cells using neutral red as an electronophore. Appl Environ Microb; 66: 1292-1297.

12. Oh SE, Logan BE. 2005, Hydrogen and electricity production from a food processing wastewater using fermentation and microbial fuel cell technologies. Water Reseach; 39: 4673-4682.
13. Suzuki S. and I. Karube, Energy Production With Immobilized. Cells, Appl. Biochem. Bioeng., Vol. 4,pp. $281-310,1983$.

14. Pranab, K. and Deka, D. 2010, Electricity Generation from Biowaste Based Microbial Fuel Cells. International Journal of Energy, Information and Communications; $1(1) ; 77-92$.

15. Xie, X; Hu, L; Pasta, M; Wells, G. F; Kong, D. and et al. 2010, Three-Dimentional Carbon Nannotube- Textile Anode for High- performance Microbial Fuel Cells. Nanno Lifters,;11(1); 291-296.11components/membranes/nafion-117

\section{Persian Abstract}

DOI: 10.5829/ijee.2018.09.03.06

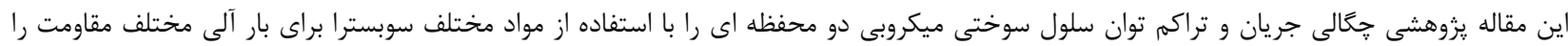

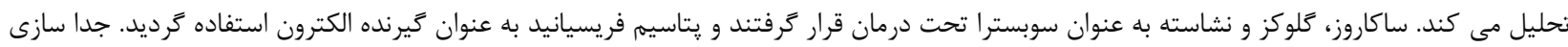

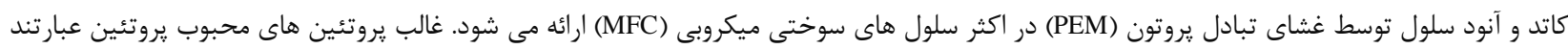

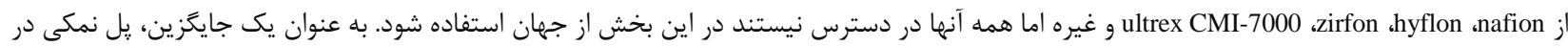

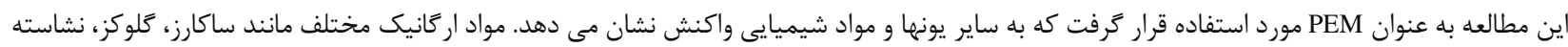

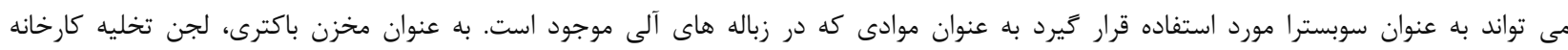
مورد استفاده قرار كرفت. ولتاز و جريان در مقاومت هاى 1 DhakaTreatment Plant

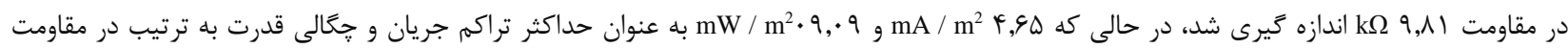

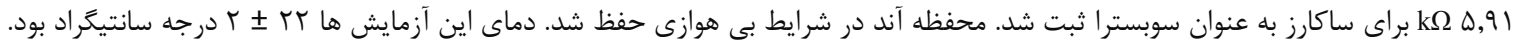

